\title{
Perilaku Merokok Pada Masyarakat Dan Implementasi Kebijakan Kawasan Tanpa Rokok (Ktr) Di Desa Ajung Kecamatan Kalisat Kabupaten Jember
}

\author{
Prehatin Trirahayu Ningrum $^{1 *}$,Reny Indrayani ${ }^{2}$ \\ ${ }^{1}$ Bagian Kesehatan Lingkungandan Kesehatan Keselamatan Kerja Fakultas Kesehatan Masyarakat-Universitas \\ Jember, Jl. Kalimantan I No.93 Jember, \\ Email:angum_ajah@yahoo.co.id \\ ${ }^{2}$ Email: renyindrayani.fkm@unej.ac.id
}

\begin{abstract}
Smoking behavior has become an important issue of public health around the world since the last decade. Indonesia is one of the developing countries which has the highest level of cigarette consumption and production. A large number of studies have shown that smoking behavior can cause adverse effects for health, but conversely, the number of smokers increased every year. Nowadays, the trend of smoking behavior has entered the category of younger age between 13 - 15 years old. The purpose of this research is to obtain a description about smoking behavior on people and about the implementation of "no-smoking area" policy in Ajung village, Kalisat district of Jember. This study uses a descriptive research design with observation method. This study was conducted in May 2014. The sample in this study is 56 peoples and 4 elementary schools. Variables researched in this study are the knowledge of smoking adverse effect, smoking activity, the age of first smoking experience, the number of cigarette smoked per day, and "nosmoking area" policy. The results of the study have shown that $60,87 \%$ respondents have knowledge about smoking adverse effect toward respiratory disorders, respondents who have smoked daily activity are about $19.64 \%$, the majority of respondents start smoking at age of 15-19 years, the average of respondents smoking as many as 13 stems in a day, and only 2 elementary schools that disposed to implement the "nosmoking area" policy in their institution. Based on these results, it is recommended the more intensive counseling about the hazards and the adverse effects of smoking behavior from various related institutions (health services, social services). Local governments is suggested to make regulations which aims to implement policy about "no-smoking area" in all institutions.
\end{abstract}

Keywords : Behavior, smoking, no-smoking area

\section{Pendahuluan}

Merokok merupakan suatu faktor yang memberikan dampak besar pada kesehatan terutama pada paru-paru. Asap rokok yang dihirup seorang perokok mengandung komponen gas dan partikel. Komponen gas terdiri dari karbon monoksida, karbon dioksida, hidrogen sianida, amoniak, oksida dari nitrogen dan senyawa hidrikarbon. Adapun komponen partikel terdiri daritar, nikotin, benzopiren, fenol, dan kadmium. Terdapat 4000 bahan kimia berbahaya dalam rokok.Bahan kimia yang berbahaya dalam rokok adalah nikotin merupakan zat adiktif dan tar yang bersifat karsinogenik. Racun dan karsinogen yang muncul akibat pembakaran tembakau dapat menyebabkan kanker (Mardiani, 2004).

Asap rokok di perokok aktif akan merangsang enzim elastase. Pelepasan enzim ini dapat merusak elastisitas paru-paru dan alveoli. Hal ini dapat membuat perokok akan terengah-engah. Merokok juga dapat merusak sel-sel philia pada saluran pernapasan. Sel dari philia memiliki fungsi sebagai espectorant. Jika sel-sel philia yang rusak kemudian dapat menumpuk dahak, maka akan menyebabkan infeksi. Perokok aktif juga berisiko menderita bronkitis kronis (batuk cronic), peningkatan asma, peningkatan karbon monoksida dalam darah, serangan jantung dan stroke.

Menghirup udara bersih tanpa paparanasap rokok telah menjadi perhatian di dunia. Namun kenyataannya adalah paparan 
asap rokok ini meningkat karena meningkatnya jumlah perokok. Asap rokok tidak hanya berdampak negatif pada perokok, tetapi juga bagi orang lain yang menghirup asap. Perokok pasif memiliki risiko lebih tinggi penyakit kardiovaskular, kanker paru-paru dan penyakit paru-paru lainnya. Asap rokok yang datang langsung pada saat menyalakan rokok (side stream smoke) dua kali lebih berbahaya dari asap rokok yang dihembuskan oleh perokok (asap utama) (Departemen Kesehatan,2004). Diperkirakan kematian di Asia meningkat hampir 4 kali dari 1,1 juta pada tahun 1990 menjadi 4,2 juta pada tahun 2020, sedangkan pada tahun 2030 angka kematian di dunia akibat konsumsi tembakau mencapai 10 juta orang setiap tahun dimana $70 \%$ terjadi di negara berkembang termasuk di Indonesia (Notoatmojo, 2010).

\section{Metode penelitian}

Metode yang digunakan dalam penelitian ini adalah metode penelitian deskriptif, yaitu suatu penelitian yang dilakukan untuk mendeskripsikan atau menggambarkan suatu fenomena yang terjadi di dalam masyarakat. ${ }^{5}$ Dengan metode observasi. Tempat penelitian di Desa Ajung Kecamatan Kalisat kabupaten Jember. Penelitian dilakukan pada bulan Mei 2014. Populasi masyarakat yang berada di Desa Ajung. Sampel penelitian sebanyak 56 sampel pada masyarakat dan 4 institusi pendidikan sekolah dasar. Cara pengambilan sampel adalah dengan purposive sampling. Intrumen yang digunakan adalah kuisioner dan lembar observasi. Variabel penelitian ini adalah Aktivitas Merokok, Usia Pertama Merokok, Jumlah Batang Rokok Setiap Hari, Pengetahuan dampak merokok dan Kebijakan KTR (Kawasan Tanpa Rokok).

\section{Hasil dan pembahasan \\ 3.1 Hasil}

Hasil penelitian ini disajikan dalam tabel 1 berikut.

Tabel 1. Distribusi Responden terhadap Aktivitas Merokok, Usia Pertama Merokok, Jumlah Batang Rokok Setiap Hari, Pengetahuan Dampak Rokok.

\begin{tabular}{|c|c|c|c|}
\hline \multirow{2}{*}{ No } & \multirow[t]{2}{*}{ Variabel } & \multicolumn{2}{|c|}{ Desa Ajung } \\
\hline & & Jumlah Responden Individu & Persentase (\%) \\
\hline \multirow[t]{5}{*}{1} & Aktivitas Merokok & & \\
\hline & 1. Setiap Hari & 11 & 19,64 \\
\hline & 2. Jarang & 2 & 3,57 \\
\hline & 3. Mantan perokok & - & - \\
\hline & 6. Bukan perokok & 43 & 76,79 \\
\hline \multirow[t]{7}{*}{2} & Usia pertama Merokok & & \\
\hline & 1. 5-9 tahun & - & - \\
\hline & 2. $10-14$ tahun & - & - \\
\hline & 3. $15-19$ tahun & 10 & 76,92 \\
\hline & 4. 20-24 tahun & 2 & 15,38 \\
\hline & 5. 25-29 tahun & 1 & 7,69 \\
\hline & $6 . \geq 30$ tahun & - & - \\
\hline \multirow[t]{2}{*}{3} & $\begin{array}{l}\text { Jumlah Batang Rokok Setiap Hari } \\
\text { 1. } 1-5 \\
\text { 2. } 6-10 \\
\text { 3. } 10-15\end{array}$ & & \\
\hline & $4 .>24$ & 13 & 100 \\
\hline \multirow[t]{5}{*}{4} & Pengetahuan Dampak Rokok & & \\
\hline & 1. Jantung & 13 & 28,26 \\
\hline & 2. Pernafasan & 28 & 60,87 \\
\hline & 3. Kanker & 16 & 34,78 \\
\hline & 4. Gangguan Kehamilan dan Janin & 2 & 2,17 \\
\hline
\end{tabular}


Dari 56 responden, didapatkan sebanyak 43 responden (76,79\%) adalah bukan perokok, 11 responden $(19,64 \%)$ adalah perokok yang merokok setiap hari, sisanya sebanyak 2 responden (3,57\%) adalah perokok tetapi jarang merokok. Dari 13 responden perokok,dodapatkan informasi mengenai usia pertama merokok yaitu pada rentang usia 15-19 tahun sebanyak 10 responden (76,92\%), pada usia 20-24 tahun sebanyak 2 responden $915,38 \%$ ), dan sisasnya 1 orang merokok pertama kali pad usia 25-29 tahun $(7,69 \%)$. Rata-rata masyarakat merokok menghabiskan rokok sebanyak 13 batang dalam sehari. PSebanyak 36 responden responden setuju bahwa rokok dapat menganggu kesehatan, dimana responden tersebut yang pengetahuan masyarakat terkait dengan dampak rokok terhadap pernafasan sebanyak 28 responden $(60,87 \%)$, sedangkan masyarakat yang mengatakan bahwa rokok berdampak terhadap kejadian kanker sebanyak 16 responden $(34,78 \%)$, yang mengatakan merokok berdampak pada jantung sebanya 13 responden $(28,26 \%)$ dan sisanya 1 responden $(2,17 \%)$ mengatakan rokok dapat menganggu kehamilan dan Janin.

\subsection{Pembahasan}

Merokok dapat menyebabkan perubahan struktur dan fungsi saluran nafas dan jaringan paru-paru.Pada saluran nafas besar, sel mukosa membesar (Hipertrofi) dan kelenjar mukus bertambah banyak (Hiperplasia).Pada saluran nafas kecil, terjadi radang ringan hingga penyempitan akibat bertambahnya sel dan penumpukan lendir.Pada jaringan paruparu, terjadi peningkatan jumlah sel radang dan kerusakan Alveolus. Akibat perubahan anatomi saluran nafas, pada perokok akan timbul perubahan pada fungsi paru-paru dengan segala macam gejala klinisnya. Hubungan antara merokok dan kanker paruparu telah diteliti dalam 4-5 dekade terakhir ini.Didapatkan hubungan erat antara kebiasaan merokok, terutama sigaret, dengan timbulnya kanker paru-paru.Bahkan ada yang secara tegas menyatakan bahwa rokok sebagai penyebab utama terjadinya kanker paru-paru. Partikel asap rokok, seperti benzapiren, dipensapiren dan ureta, dikenal sebagai bahan karsinogen. Juga tar berhubungan dengan risiko terjadinya kanker (Bernida,2003).

Tembakau sebagai bahan baku rokok mengandung bahan toksik yang dapat mempengaruhi kondisi kesehatan, dengan demikian tenaga kerja yang mempunyai kebiasaan merokok mendapatkan risiko atau pemicu keluhan subyektif saluran pernapasan dan gangguan ventilasi paru, dan tenaga kerja yang perokok merupakan salah satu faktor risiko penyebab penyakit saluran pernapasan (Adams, 2009).

Merokok bertanggung jawab $90 \%$ dari semua kanker paru-paru, $75 \%$ dari radang saluran pernafasan yang kronis dan emfisema, serta 25\% dari kasus penyakit jantung iskemik. Kebiasaan merokok menurut JAMA tahun 1994 telah membagi menjadi tiga kategori perokok yaitu Perokok ringan, bila jumlah rokok yang dihisap antara $1-6$ batang perhari, Perokok Sedang, bila jumlah rokok yang dihisap antara $7-12$ batang perhari, Perokok Berat, Bila jumlah rokok yang dihisap lebih dari 12 batang perhari.

Dari hasil analisis kesehatan terkait dengan rokok diatas maka peneliti mengadakan program kegiatan terkait dengan masalah rokok pada masyarakat Dusun Ajung Kecamatan Kalisat Kabupaten Jember . Program ini salah satunya dilaksanakan di Institusi pendidikan yang berada di desa Ajung kecamatan Kalisat kabupaten Jember yaitu berupa program penyuluhan tentang bahaya dan kandungan rokok dan pengajuan terbentuknya Kawasan Tanpa Rokok (KTR) di instansi pendididkan desa Ajung kecamatan Kalisat kabupaten Jember.

Upaya pembentukan KTR (Kawasan Tanpa Rokok) diberikan kepada setiap kepala sekolah dasar di desa Ajung untuk meningkatkan kewaspadaan terhadap 
penyakit infeksi saluran pernafasan dengan membentuk suatu tempat tersendiri untuk wilayah merokok. Program ini awalnya terbentuk dari adanya pelaksanaan Musyawarah Masyarakat Desa (MMD), banyak masyarakat yang mengeluhkan bahwa banyak terjadi kejadian infeksi saluran pernafasan yang terutama diakibatkan oleh asap rokok. Sasaran ditujukan kepada setiap kepala sekolah agar dapat membentuk kawasan tanpa rokok untuk mengurangi ISPHA (Infeksi Saluran Pernafasan) di lingkungan sekolah sehingga diadakan kegiatan pembentutan KTR.

Kegiatan pembentukkan KTR dilaksanakan di beberapa sekolah dasar di desa Ajung antara lain SDN 1 Ajung, SDN 2 Ajung, SDN 3 Ajung, dan SDN 5 Ajung. Kegiatan ini dilaksankan pada tanggal 15, 16 dan 17 Juli 2014. Tujuan dilaksanakan kegiatan pembentukan KTR ini adalah 50\% SDN di desa Ajung melaksanakan KTR.Keberhasilan dari program ini diukur dengan telah terbentuknya kawasan tanpa rokok di sekolah dasar tersebut.

Hasil dari efektifitas kegiatan pembentukan KTR (Kawasan Tanpa Rokok) dilihat dari kreteria evaluasi yaitu minimal terbentuk 1 instansi pendidikan yang menyetujui draft KTR yang diajukan dan hasilnya terdapat 2 instansi pendidikan yang menyetujui draft KTR antara lain SDN 01 Ajung dan SDN 03 Ajung. Untuk 2 SDN yang lain tidak menyetujui adanya pembentukan KTR di wilayah sekolahnya. Komponen dalam pembentukan dalam implementasi KTR adalah Kesiapan sekolah, kebijakan pimpinan, dan konsistensi guru/staf dalam menjalankan untuk tidak berperilaku merokok di Sekolah. Hal ini dikarenakan masih banyaknya guru laki-laki yang berperilaku merokok di area sekolah. Bahkan untuk kepala sekolahnya sendiri mempuntai perilaku merokok. Sehingga kegiatan KTR tdk dapat berjalan.

Selama kegiatan berlangsung, hambatan yang dialami yaitu pada saat kepala sekolah salah satu sekolah dasar yang merangkap kepala sekolah di sekolah dasar lainnya sehingga konsentrasi terpecah.Tetapi selama kegiatan berlangsung cukup lancar. Kesiapan sekolah dalam mengimplementasikan KTR adalah hanya pada batas pemasangan banner untuk peringatan KTR. Rendahnya kesadaran masyarakat tentang bahaya merokok pun menjadi alasan sulitnya penetapan Kawasan Tanpa Rokok (KTR), yang ditunjukkan dengan mulai merokok pada kelompok usia 59 tahun. Konsumsi rokok paling rendah terjadi pada kelompok umur 15-24 tahun dan kelompok umur 75 tahun ke atas. Hal ini berarti kebanyakan perokok adalah generasi muda atau usia produktif. Selanjutnya, pada daerah pedesaan, jumlah batang rokok yang dikonsumsi lebih banyak dibanding daerah perkotaan.

Efektifitas pemberlakuan kawasan tanpa rokok telah ditunjukkan bebrapa penelitian. Hasil kajian terhadap efek pemberlakuan kebijakan Sekolah Bebas Rokok terhadap perilaku merokok remaja, melaporkan bahwa pemberlakuan kebijakan sekolah tanpa rokok mengurangi perilaku merokok siswa di sekolah (Prabandari,2009).

Pemberlakuan kawasan tanpa rokok secara langsung akan memberikan dampak terhadap tidak adanya asap rokok, bila para pelaku merokok mematuhi kebijakan tersebut. Demikian pula para perokok akhirnya hanya mempunyai peluang terbatas untuk merokok (Kemenkes RI,2011).

\section{Kesimpulan}

Aktivitas masyarakat merokok ada pada kategi setiap hari, sedangkan untuk usia pertama merokok berada pada rentan usia 1519 tahun dengan rata-rata mengahabiskan 13 batang rokok/hari. Sebagian besar responden berpendapat dampak merokok adalah mengakibatkan gangguan pernafasan. Terdapat 2 instansi pendidikan yang menyetujui KTR.

Kerjasama berbagai pihak dalam proses pendekatan kepada masyarakat khususnya 
pada Dinas Kesehatan untuk melakukan penyuluhan terkait dengan merokok dan pengawasan area KTR. Selain itu Perlu adanya peraturan dari PEMDA agar kebijakan terkait dengan KTR dapat dijalankan disemua Instansi.

\section{Daftar pustaka}

Adams ML, dkk. The Relationship Between Tobacco School Policies and youth Tobacco Use. Journal of Scholl Health, 2009;79:17-23

Bernida I, Yunus F, Wiyono WH, dkk. Faal Paru dan Uji Bronkodilator pada Perokok dan bukan Perokok. J Respir Indo, June 21, 2003 ; 10:411. Cermin Dunia Kedokteran

Departemen Kesehatan. The Tobacco Sourse Book: Data to Support a national Tobacco Control Strategy. Jakarta. 2004

Kemenkes RI. Pedoman Pengembangan Kawasan Tanpa Rokok. Pusat Promosi Kesehatan. Jakarta. 2011

Kosen,S. Perhitungan beban Ekonomi Tembakau berdasarkan Data Penyakit dan Biaya RS 2005. Dipresentasikan pada KONAS IAKMI 2007. Tidak dipublikasikan. 2007.

Mardiani,T.H. Jurnal: Bahan Kimia dalam Rokok, Fakultas kedokteran, Universitas Sumatera Utara. http://www.library.usu.ac.id. $\quad$ (12 Agustus 2012 Citation). 2004

Notoatmojo.Metodologi Penelitian Kesehatan.Jakarta:PT Rineka Cipta. 2010

Prabandari, dkk. Kawasan tanpa Rokok sebagai Alternatif pengendalian Tembakau Studi Efektifitas Penerapan Kebijakan Kampus Bebas Rokok Terhadap Perilaku dan Status Merokok Mahasiswa di fakultas Kedokteran UGM Yogtakarta. Bagian Ilmu Kesehatan Masyarakat FK UGM, 2009;6-8

Subroto, H. Pengaruh rokok terhadap timbulnya PPOM. Penyakit Obstruktif Menahun patogenesis dan pengelolaan menyeluruh. Badan
Penerbit Universitas Diponegoro, Semarang. 2004 